\title{
The relationship between eastern and western populations of the Heath Rat, Pseudomys shortridgei (Rodentia: Muridae)
}

\author{
N.K. Cooper ${ }^{1}$, T. Bertozzi², Alexander Baynes ${ }^{1}$ and R.J. Teale ${ }^{3}$ \\ ${ }^{1}$ Western Australian Museum, Francis Street, Perth, Western Australia 6000 Australia \\ ${ }^{2}$ Evolutionary Biology Unit, South Australian Museum, North Terrace, Adelaide, South Australia 5000, Australia \\ ${ }^{3}$ BIOTA Environmental Sciences, 186 Scarborough Beach Road, Mount Hawthorn, Western Australia 6016, Australia
}

The Heath Rat, Pseudomys shortridgei (Thomas, 1907), has a wide but disjunct range across southern Australia, occurring in heaths and shrublands in western Victoria, southern South Australia and Western Australia (Cockburn 1995). The holotype of P. shortridgei (Natural History Museum, London, no. 6.8.1.73) was collected by G.C. Shortridge on 27 Apr 1906 from Woyerling, east of Pingelly, Western Australia (Tate 1951) (see Figure 1). Shortridge (1936) recorded the locality as "Woyaline Wells (source of the Avon River)". In Western Australia it is presently known only from Fitzgerald River National Park, Lake Magenta Reserve, Dragon Rocks Reserve, Hyden area and Ravensthorpe (specimens in the Western Australian Museum collection) (Figure 1). Two specimens were also accessioned into the Western Australian Museum collection in 1931 from the Lake Biddy area.

The distribution of Pseudomys shortridgei was much more extensive in southwestern Australia prior to European colonisation (Figure 1), ranging from the west coast of Shark Bay to the Great Australian Bight. Although this area encompasses six Interim Biogeographic Regionalisation of Australia regions (IBRA - Thackway and Creswell [1995]), varied habitat types and differing rainfall regimes, $P$. shortridgei is not recorded from all IBRA regions or habitat types within its former range (Figure 1).

The rediscovery of living populations of Pseudomys shortridgei in Western Australia was described by Baynes et al. (1987), and the species is currently listed as Declared Threatened Fauna in that State (Wildlife Conservation Notice 2001).

In eastern Australia, Pseudomys shortridgei now occurs almost exclusively in recently burnt, species-rich, treeless, dry heathlands in southeastern South Australia and southwestern Victoria (Cockburn 1995). It is dependent on postfire regrowth (Cockburn et al. 1981) and the optimum situation for the species appears to be a mosaic of habitats of differing maturity, subject to disturbance by fire (Cockburn 1978). According to the Commonwealth of Australia (1999), the species is classified as Mammals that are Vulnerable.

In a review of the fauna recorded from the Fitzgerald Biosphere Reserve, Chapman et al. (unpublished) compiled 77 records of this species (excluding the nine specimens in the Western Australian Museum collection). Vegetation of the sites varied, as did soil type. The predominant vegetation was shrub mallee over either heath or scrub over sedges. Sedges are thought to be an important dietary component (A. Sanders personal communication 2003). Some individuals were also trapped in shrublands on granites and low forest principally comprising Eucalyptus gardneri ravensthorpensis. Soils included loamy sands or sandy loams with a lateritic scree and clayey soils with a stony component. Pseudomys shortridgei has been recorded from a range of profiles on the landscape including a seasonally damp site low in the landscape and on top of a rocky ridge, about 40 metres high. Most records came from long unburnt vegetation (between 30 and 70 years) although Chapman et al. (unpublished) recorded five individuals from two sites in 2000 that had been previously burnt in November 1980 . However, the apparent preference for long unburnt vegetation, which contrasts to eastern populations, may reflect a general paucity of trapping in recently burnt suitable habitat in Western Australia.

A survey by the Western Australian Museum along the coast of the Great Australian Bight in late summer 1984 failed to record Pseudomys shortridgei at Israelite Bay, Toolinna Cove, Eyre Bird Observatory or Eucla. Both Elliott and pitfall traplines were employed at all of these locations ( $R$. How personal communication 2003). No $P$. shortridgei were trapped during the Nullarbor surveys in 1984 (Boscacci et al. 1987). These surveys suggest that the extant eastern and western populations of $P$. shortridgei are now disjunct, with a distance of about $1800 \mathrm{~km}$ between them.

The eastern and western populations have probably been separated for only a few thousand years. Surface remains from mainly coastal caves 


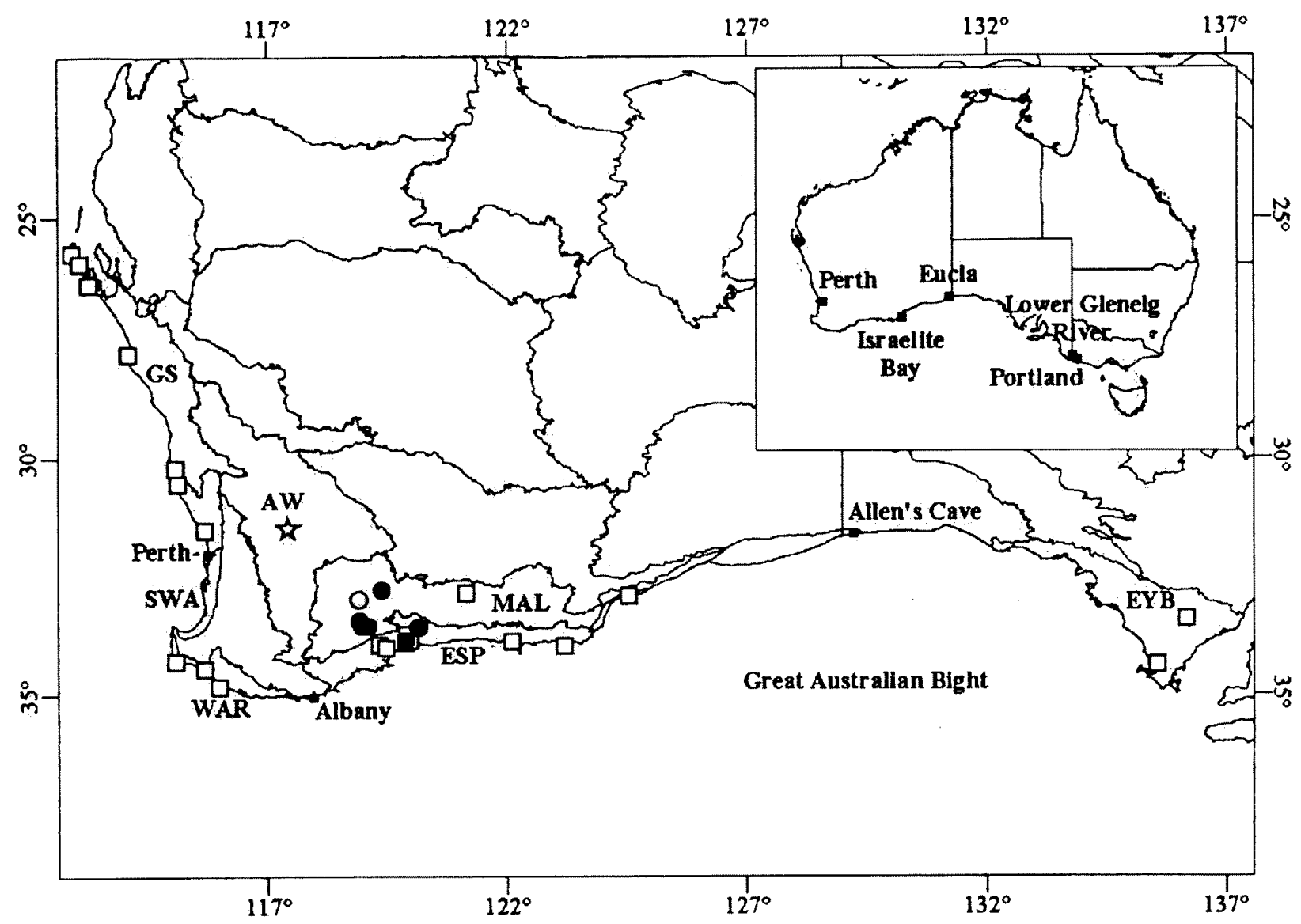

Figure 1 Map of southern Australia showing IBRA regions with former (open square), modern Western Australian Museum (pre 1983 open circles, post 1983 closed circles) locality records of Pseudomys shortridgei. The holotype, (collected 1906) is represented by a star. IBRA regions: AW, Avon Wheatbelt; ESP, Esperance Plains; EYB, Eyre Yorke Block; GS, Geraldton Sandplains; MAL, Mallee; SWA, Swan Coastal Plain; WAR, Warren.

(Baynes 1987) show that Pseudomys shortridgei occurred along the southern coast of Western Australia to at least the eastern end of the Wylie Scarp, on the western side of the Great Australian Bight, and on the Eyre Peninsula to the east, in immediately pre-European times (Figure 1). The species is also a component of the late Holocene fauna from Venus Bay near Ceduna (McDowell 1997) and is even sparsely recorded from the grey upper deposit in Allen's Cave, which lies near the eastern extremity of the mallee belt just east of the border between Western and South Australia. The grey upper deposit is of late Holocene age (Roberts et al. 1996). During the last Pleistocene glacial (oxygen isotope stages 2 and 3), sea-level was lower and the present Great Australian Bight was a sandy coastal plain up to $120 \mathrm{~km}$ wide (e.g. Bowler 1982). Fossil faunas (which include $P$. shortridgei) from both Devils Lair in southwestern Australia (Baynes et al. 1976; Balme et al. 1978) and Seton rock shelter on what is now Kangaroo Island (Hope et al. 1977), show that mammal communities in southern coastal areas during the last glacial had greater speciesrichness than those of the Holocene interglacial, probably because glacial climates were less seasonal. All these points suggest that there was a continuous population of $P$. shortridgei along the central southern coast of Australia during much if not all of the last glacial.

Several other mammal taxa which also inhabit shrub formations and that are currently judged to be the same species on both sides of the Bight, shared this original distribution pattern: Parantechinus apicalis, Isoodon obesulus, Potorous platyops, Macropus eugenii, Cercartetus concinnus, Pseudomys occidentalis and Rattus fuscipes (Baynes 1987; distribution maps in Strahan 1995). Notomys mitchellii had a similar though continuous distribution in immediately pre-European times. In contrast, neither Pseudomys albocinereus nor $P$. apodemoides has been recorded from either Eyre Peninsula or Kangaroo Island, even as a fossil. These two species were synonymised by Ride (1970), and have been assumed to be a 'sibling pair' (but see below).

From recent survey work in Western Australia, in areas where Pseudomys shortridgei is known to be extant, few individuals have been trapped. From 4460 Elliott trap-nights (medium size Elliott traps) and 1494 pitfall trap-nights within the Fitzgerald 
Biosphere Reserve between 1993 and 2001, just 77 capture events were recorded from 11 sites. This is much less than the 708 capture events of the Bush Rat, Rattus fuscipes across 47 sites during the same studies (Chapman et al. unpublished). In Victoria, Happold (1976) and Braithwaite (1977) found that the density of animals in favoured areas was six per hectare and that numbers did not vary temporally.

Before there is further work to study the size, extent and status of the populations of Pseudomys shortridgei in Western Australia, it is important to know whether the well-studied eastern populations belong to the same species as the populations in Western Australia. If they are different species, then information on the biology of the eastern populations may not be suitable as a basis for management in Western Australia. There have been no previously published morphological or molecular genetic studies to examine if the two populations are indeed the same species. The first step in the evaluation of the taxonomic status of the western and eastern populations has been the molecular genetic analysis of tissues from eastern and western specimens.

We nucleotide sequenced approximately 300 base pairs of the mitochondrial cytochrome $b$ gene by polymerase chain reaction amplification and direct sequencing using the primers H15149 and L14841 (Kocher et al. 1989). Specimens used in this study are listed in Table 1. An evolutionary tree of the aligned sequences constructed with the NeighbourJoining algorithm from Kimura 2-parameter distances showed that there is a split between the Western Australian and eastern states samples (two only of the latter) at about $2.6 \%$ sequence divergence on average (Table 2). This level of divergence is less than that seen between species of Pseudomys, for instance distances between species of pebble-mound mice exceed $5.6 \%$ uncorrected sequence divergence and the distance between the east-west 'sibling' species Pseudomys albocinereus

Table 1 Collection data for specimens used in molecular analysis. Prefixes for registration numbers are WAMM - Western Australian Museum mammal collection; ABTC Australian Biological Tissue Collection, South Australian Museum.

\section{Western Australia}

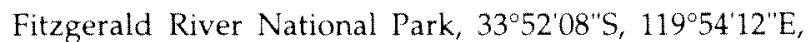
WAMM26644; Lake Magenta Reserve, 333'00"S, $118^{\circ} 58^{\circ} 00^{\prime \prime E}$, WAMM41908, WAMM49272-3; Lake Magenta Reserve, $33^{\circ} 28^{\circ} 01^{\prime \prime S}, 118^{\circ} 55^{\circ} 01^{\prime \prime}$, WAMM52338

\section{South Australia}

Lower Glenelg River CP, 38 $00^{\circ} 00^{\prime \prime} S, 140^{\circ} 57^{\circ} 00^{\prime \prime}$, ABTC79270

\section{Victoria}

$6 \mathrm{~km}$ W Portland, 38 $20^{\prime} 00^{\prime \prime} \mathrm{S}, 141^{\circ} 32^{\prime} 00^{\prime \prime} \mathrm{E}, \mathrm{ABTC} 8079$
Table 2 Distance matrix of uncorrected genetic distances (percentages) of partial mitochondrial cytochrome $b$ sequences for Pseudomys shortridgei

\begin{tabular}{llllllll}
\hline & 1 & 2 & 3 & 4 & 5 & 6 & 7 \\
1 ABTC8079 & - & & & & & & \\
2 ABTC79270 & 0.000 & - & & & & \\
3 WAMM26644 & 0.026 & 0.026 & - & & & \\
4 WAMM41908 & 0.026 & 0.026 & 0.000 & - & & \\
5 WAMM49272 & 0.026 & 0.026 & 0.000 & 0.000 & - \\
6 WAMM49273 & 0.026 & 0.026 & 0.007 & 0.007 & 0.007 & - \\
7 WAMM52338 & 0.026 & 0.026 & 0.000 & 0.000 & 0.000 & 0.007 & - \\
\hline
\end{tabular}

and $P$. apodemoides is $12 \%$ for the same sequence. However, mitochondrial DNA analyses (Torrance and Donnellan unpublished observations) suggest that Pseudomys albocinereus and $P$. apodemoides are not sister taxa. There is minor divergence $(0.7 \%)$ between individuals of $P$. shortridgei in the Lake Magenta area in Western Australia and no divergence between the two eastern states samples.

Taken together, the data on historical distribution, ecology and genetic divergence suggest recent separation of eastern and western Pseudomys shortridgei populations and support the present treatment of those populations as a single species. The level of molecular divergence between Western Australian and South Australian and Victorian samples is low compared with differences among sibling species of Pseudomys, and furthermore the reciprocal monophyly of the eastern and western mitochondrial lineages (if indeed this still holds up with a larger number of individuals sampled) could have arisen quickly following a rapid diminution in range and consequent population decline following the last glacial just a few thousand years ago. That the western and eastern populations appear to occupy different habitats may simply reflect the lack of identical habitats in the two widely separated regions. It would be desirable to confirm the status of the populations with a morphological study.

\section{ACKNOWLEDGEMENTS}

The authors thank BHP Billiton Ravensthorpe Nickel Operations Pty Ltd for funding the molecular analysis, Piers Higgs for producing Figure 1, John Dell, Steve Donnellan and Ric How for constructive comments on the manuscript and Angela Sanders and Andy Chapman for providing trapping information

\section{REFERENCES}

Balme, J.M., Merrilees, D. and Porter, J.K. (1978). Late Quaternary mammal remains, spanning about 30000 years, from excavations in Devil's Lair, Western 
Australia. Iournal of the Royal Society of Western Australia 61: 33-65.

Baynes, A. (1987). The original mammal fauna of the Nullarbor and southern peripheral regions: evidence from skeletal remains in superficial cave deposits. In McKenzie, N.L. and Robinson, A.C., eds. A biological survey of the Nullarbor region South and Western Australia in 1984. Adelaide: South Australian Department of Environment and Planning. Pp. 139$145 ; 400-401$.

Baynes, A., Chapman, A. and Lynam, A.J. (1987). The rediscovery, after 56 years, of the Heath Rat Pseudomys shortridgei (Thomas, 1907) (Rodentia: Muridae) in Western Australia. Records of the Western Ausralian Museum 13: 319-322.

Baynes, A., Merrilees, D. and Porter, J.K. (1976). Mammal remains from the upper levels of a late Pleistocene deposit in Devil's Lair, Western Australia. Journal of the Royal Society of Western Australia 58: 97-126.

Boscacci, L.J., McKenzie, N.L. and Kemper,C.M. (1987). Mammals. In McKenzie, N.L. and Robinson, A.C., eds. A biological survey of the Nullarbor region South and Western Australia in 1984. Adelaide: South Australian Department of Environment and Planning. Pp. 103138.

Bowler, J.M. (1982). Aridity in the late Tertiary and Quaternary of Australia. In Barker, W.R. and Greenslade, P.J.M., eds. Evolution of the flora and fauna of arid Australia. Adelaide: Peacock Publications. Pp. 35-45.

Braithwaite, R.W. (1977). Preliminary observations on the activity pattern of Rattus lutreolus and other Victorian small mammals. Victorian Naturalist 94: 216-219.

Chapman, A., Sanders, A., Harold, G. and Teale, R.J. (unpublished). Vertebrate fauna of the Fitzgerald Biosphere Reserve.

Cockburn, A.R. (1978). The distribution of Pseudomys shortridgei (Muridae: Rodentia) and its relevance to that of other heathland Pseudomys. Australian Wildlife Research 5: 213-219.

Cockburn, A.R. (1995). Heath Rat Pseudomys shortridgei (Thomas, 1907). In Strahan, R., ed. The mammals of Australia. Reed Books. Pp. 617-618.

Cockburn, A.R., Braithwaite, R.W. and Lee, A.K. (1981). The response of the Heath Rat, Pseudomys shortridgei to pyric succession: a temporally dynamic life-history strategy. Journal of Animal Ecology 50: 649-666.

Commonwealth of Australia (1999). Environment Protection and Biodiversity Conservation Act 1999.

Government of Western Australia (2001). Wildlife Conservation (Specially Protected Fauna) Notice 2001. Government Gazette. Pp. 4238-4245.
Happold, M. (1976). Social behaviour of the conilurine rodents (Muridae) of Australia. Zeitschrift für Tierpsychologie 40: 113-82.

Hope, J.H., Lampert, R.J., Edmondson, E., Smith, M.J. and Van Tets, G.F. (1977). Late Pleistocene faunal remains from Seton rock shelter, Kangaroo Island, South Australia. Journal of Biogeography 4: 363-385.

Kocher, T., Thomas, W., Meyer, A., Edwards, S., Pääbo, S., Villablanca, F. and Wilson, A. (1989). Dynamics of mitochondrial DNA evolution in animals: amplification and sequencing with conserved primers. Proceedings of the National Academy of Sciences, USA 86: 6196-6200.

McDowell, M.C. (1997). Taphonomy and palaeoenvironmental interpretation of a late Holocene deposit from Black's Point Sinkhole, Venus Bay, S.A. Proceedings of the Linnean Society of New South Wales 117: 76-95.

Ride, W.D.L. (1970). A guide to the native mammals of Australia. Oxford University Press, Melbourne. Pp. ixiv, 1-249.

Roberts, R.G., Spooner, N.A., Jones, R., Cane, S., Olley, J.M., Murray, A.S. and Head, M.J. (1996). Preliminary luminescence dates for archaeological sediments on the Nullarbor Plain, South Australia. Australian Archaeology No. 42: 7-16.

Shortridge, G.C. (1936). Field notes (hitherto unpublished) on Western Australian mammals south of the tropic of Capricorn (exclusive of Marsupialia and Monotremata), and records of specimens collected during the Balston Expeditions (November 1904 to June 1907). Proceedings of the Zoological Society of London 1936: 743-749.

Strahan, R., ed. (1995). The mammals of Australia. Reed Books, Chatswood, N.S.W. Pp. 1-756.

Tate, G.H.H. (1951). Results of the Archbold Expeditions. No. 65. The rodents of Australia and New Guinea. Bulletin of the American Museum of Natural History 97 : 183-430.

Thackway, R. and Creswell, I.D. (1995). An interim biogeographic regionalisaton for Australia: a framework for setting priorities in the national reserves system cooperative program. Reserves System Unit. ANCA. Canberra.

Thomas, O. (1907). List of further collections of mammals from Westwern Australia, including a series from Bernier Island, obtained for Mr. W.E. Balston; with field-notes by the collector, Mr. G.C. Shortridge. Proceedings of the Zoological Society of London 1906: 763-777.

Manuscript received 11 March 2003; accepted 00 March 2003 


\section{CONTENTS VOLUME 21}

\section{Part 1}

\section{A.M. Pinder and S.A. Halse}

Two new species of Ainudrilus (Clitellata: Tubificidae) from south-western Australia, with notes on Ainudrilus nharna Pinder and Brinkhurst

\section{D.J. Kitchener and A. Suyanto}

Morphological variation in Miniopterus pusillus and M. australis (sensu Hill 1992) in southeastern Asia, New Guinea and Australia

\section{M.S. Harvey}

A new species of Austrarchaea (Araneae: Archaeidae) from Western Australia

\section{K.S.W. Campbell, R.E. Barwick, B.D.E. Chatterton and T.R. Smithson}

A new Middle Devonian dipnoan from Morocco: structure and histology of the dental plates

P. Kott

Culeolus herdmani Sluiter, 1904 (Ascidiacea, Tunicata) from the northwestern Australian continental slope with an overview of the genus

\section{A.J. Bruce}

Leander manningi, a new palaemonine shrimp from Western Australia (Crustacea,

Decapoda, Palaemonidae), with a review of the Indo-West Pacific species of the genus

Leander E. Desmarest, 1849

\section{J.H. Bradbury}

Melitid amphipods of Barrow Island, Western Australia Part II - recent discoveries

\section{SHORT COMMUNICATIONS}

\section{M.S. Harvey and E.S. Volschenk}

A forgotten scorpion: the identity of Buthus flavicruris Rainbow, 1896 (Scorpiones), with notes on Urodacus manicatus (Thorell)

\section{A.C. Gill and J.B. Hutchins}

Paramonacanthus oblongus, the correct name for the Indo-Pacific fish currently called P. japonicus, with a recommendation on the nomenclature of Stephanolepis cirrhifer 


\section{Part 2}

\section{R.M. St Clair}

Western Australian Triplectidinae (Trichoptera: Leptoceridae): descriptions of the female of Triplectides niveipennis and larvae belonging to four genera

\section{A. Reid}

Western Australian Onychophora (Peripatopsidae): a new genus, Kumbadjena, for a southern species-complex

\section{K.J. McNamara and O.H. Melikov}

The asterostomatid echinoid Antillaster from the Paradash Group (Middle Eocene) of the Nakhichevan Region of Azerbaijan

\section{K.S.W. Campbell and R.E. Barwick}

The axial postcranial structure of Griphognathus whitei from the Upper Devonian Gogo

Formation of Western Australia: comparisons with other Devonian dipnoans

E.M. Exley

Bees of the Euhesma crabronica species-group (Hymenoptera: Colletidae: Euryglossinae)

J.B. Hutchins

Description of a new genus and species of miniature monacanthid fish from the

Seychelles and Marshall Islands

\section{Part 3}

\section{M.J. Fletcher and M.L. Moir}

Cryptobarsac rubriops, a new genus and species of selizine Flatidae (Hemiptera:

Fulgoromorpha) from grasstrees (Xanthorrhoea preissii) in south Western Australia

J.M. Waldock

Redescription of Lycidas chrysomelas (Simon) (Araneae: Salticidae)

M.C. Ebach and K.J. McNamara

A systematic revision of the family Harpetidae (Trilobita)

F.E. Wells

Seasonality of beachwrack at Oakajee in the mid-west region of Western Australia

\section{K.D. Smith, B. Knott and E.J. Jasinska}

Biology of the Black-stripe minnow Galaxiella nigrostriata, (Galaxiidae) in an acidic, black-water lake in Melaleuca Park near Perth, Western Australia

\section{K.D. Smith, L.J. Pen and B. Knott}

Genetic and morphological study of the Black-stripe minnow, Galaxiella nigrostriata (Salmoniformes: Galaxiidae), including a disjunct population near Perth, Western Australia

\section{B. Knott, E.J. Jasinska and K.D. Smith}

Limnology and aquatic fauna of EPP 173, Melaleuca Park, refuge for an outlier population of the Black-stripe minnow Galaxiella nigrostriata (Galaxiidae), in southwestern Australia

\section{Yu Wen}

Very old patelliform gastropods from the Early Cambrian of China: Reconsideration of the systematic position of Archaeotremaria 


\section{Part 4}

\section{A.M. Pinder}

New species and records of Phreodrilidae (Annelida: Clitellata) from

Western Australia

\section{Karanovic}

A new genus of Candoninae (Crustacea, Ostracoda, Candonidae) from the subterranean waters of southwestern Western Australia

N.K. Cooper, M. Adams, C. Anthony and L.H. Schmitt

Morphological and genetic variation in Leggadina (Thomas, 1910) with special

reference to Western Australian populations

M.L. Moir, J.D. Majer and M.J. Fletcher

New records for Hemiptera species in Western Australia

\section{R.A. King}

First valid record of Astacilla Cordiner, 1793 in Australia, with description of a new species (Crustacea: Isopoda: Arcturidae)

\section{SHORT COMMUNICATION}

N.K. Cooper, T. Bertozzi, A. Baynes and R.J. Teale

The relationship between eastern and western populations of the Heath Rat,

Pseudomys shortridgei (Rodentia: Muridae) 


\section{INDEX TO AUTHORS}

Adams, M. .

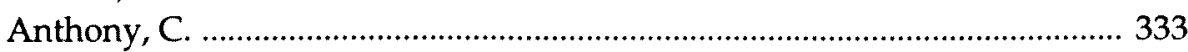

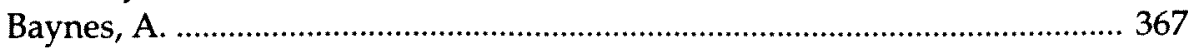

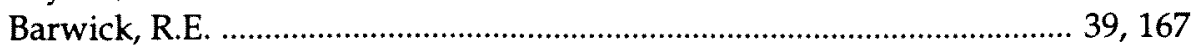

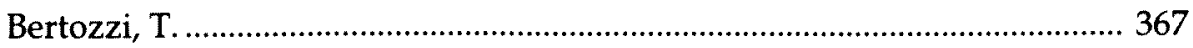

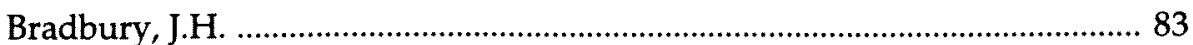

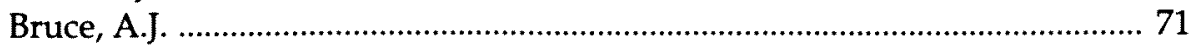

Campbell, K.S.W........................................................................ 39, 167

Chatterton, B.D.E.

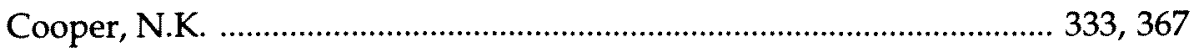

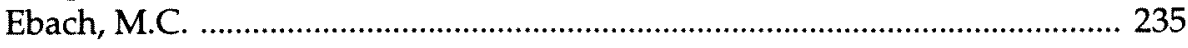

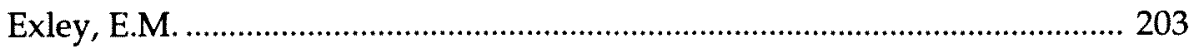

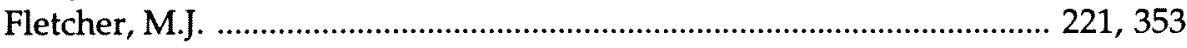

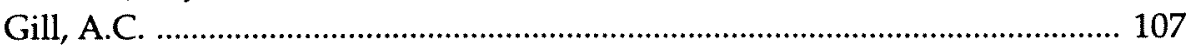

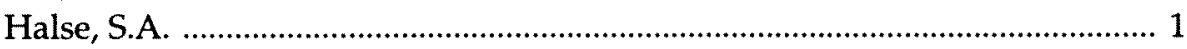

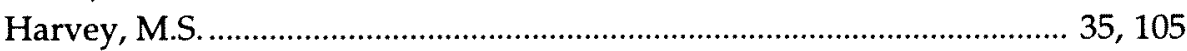

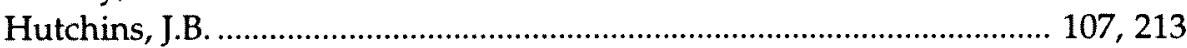

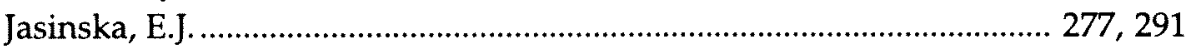

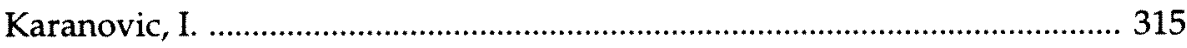

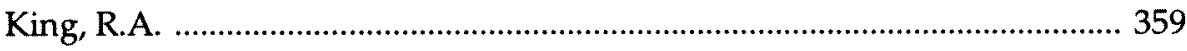

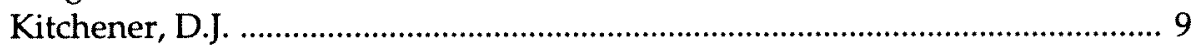

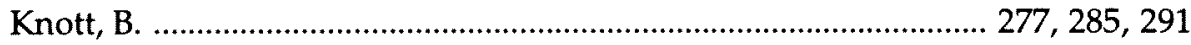

Kott, P. .

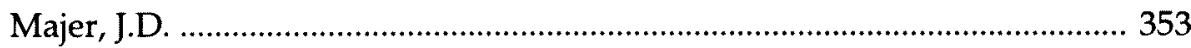

McNamara, K.J. ....................................................................... 157, 235

Melikov, O.H.

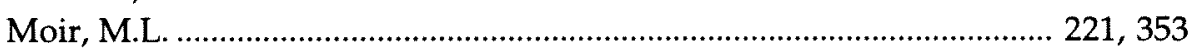

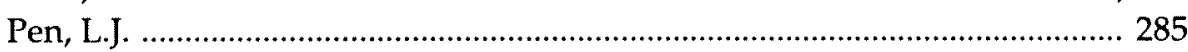

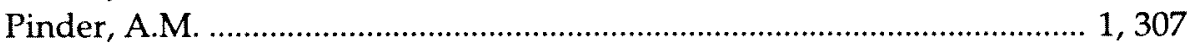

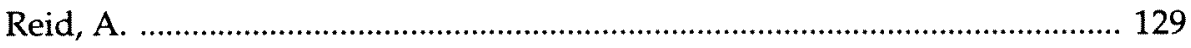

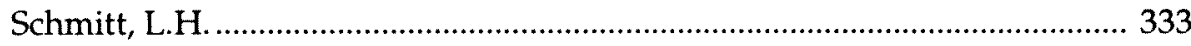

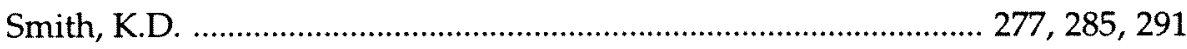

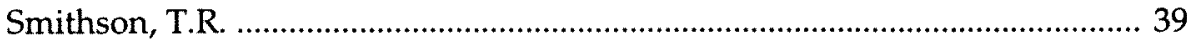

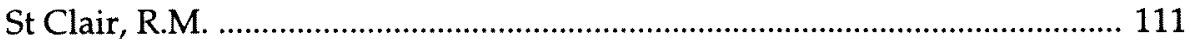

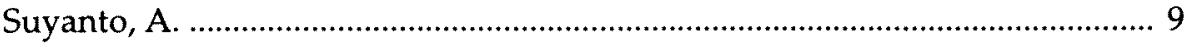

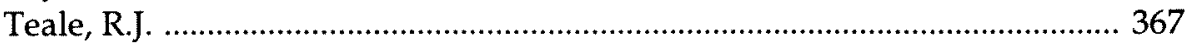

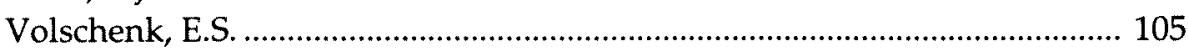

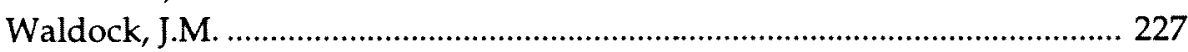

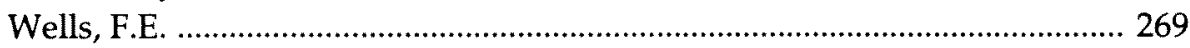

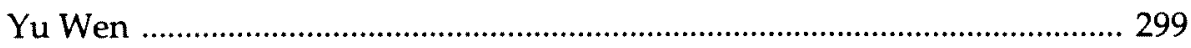




\section{Guide to Authors}

\section{Subject Matter:}

Reviews, observations and results of research into all branches of natural science and human studies will be considered for publication. However, emphasis is placed on studies pertaining to Western Australia. Longer papers will be considered for publication as a Supplement to the Records of the Western Australian Museum. Short communications should not normally exceed three typed pages and this category of paper is intended to accommodate observations, results or new records of significance, that otherwise might not get into the literature, or for which there is a particular urgency for publication. All material must be original and not have been published elsewhere.

\section{Presentation:}

Authors are advised to follow the layout and style in the most recent issue of the Records of the Western Australian Museum including headings, tables, illustrations and references.

The title should be concise, informative and contain key words necessary for retrieval by modern searching techniques. An abridged title (not exceeding 50 letter spaces) should be included for use as a running head.

An abstract must be given in full length papers but not short communications, summarizing the scope of the work and principal findings. It should normally not exceed $2 \%$ of the paper and should be suitable for reprinting in reference periodicals.

The International System of units should be used.

Numbers should be spelled out from one to nine in descriptive text; figures used for 10 or more. For associated groups, figures should be used consistently, e.g. 5 to 10 , not five to 10 .

Spelling should follow the Concise Oxford Dictionary.

Systematic papers must conform with the International Codes of Botanical and Zoological Nomenclature and, as far as possible, with their recommendations.

Synonymies should be given in the short form (taxon, author, date, page) and the full reference cited at the end of the paper. All citations, including those associated with scientific names, must be included in the references.

\section{Manuscripts:}

The original and two copies of manuscripts and figures should be submitted to the Editors, c/Publications Department, Western Australian Museum, Francis Street, Perth, Western Australia 6000. They must be in double-spaced typescript on A4 sheets. All margins should be at least $30 \mathrm{~mm}$ wide. Tables plus heading and legends to illustrations should be typed on separate pages. The desired position for insertion of tables and illustrations in the text should be indicated in pencil. Tables should be numbered consecutively, have headings which make them understandable without reference to the text, and be referred to in the text.

High quality illustrations are required to size $(16.8 \mathrm{~cm} \times 25.2 \mathrm{~cm})$ or no larger than $32 \mathrm{~cm} \times 40$ $\mathrm{cm}$ with sans serif lettering suitable for reduction to size. Photographs must be good quality black and white prints, not exceeding $16.8 \mathrm{~cm} \times 25.2 \mathrm{~cm}$. Scale must be indicated on illustrations. All maps, line drawings, photographs and graphs, should be numbered in sequence and referred to as Figure/s in the text and captions. Each must have a brief, fully explanatory caption. On acceptance a computer disk containing all corrections should be sent with amended manuscript. The disk should be marked with program (e.g. Word, WordPerfect, etc).

In papers dealing with historical subjects references may be cited as footnotes. In all other papers references must be cited in the text by author and date and all must be listed alphabetically at the end of the paper. The names of journals are to be given in full.

\section{Processing:}

Papers and short communications are reviewed by at least two referees and acceptance or rejection is then decided by the editors.

The senior author is sent one set of page proofs which must be returned promptly.

The senior author will receive fifty free offprints of the paper. Additional offprints can be ordered at page proof stage. 


\section{Records of the Western Australian Museum Volume 21 Part 42003}

\section{CONTENTS}

A.M. Pinder

New species and records of Phreodrilidae (Annelida: Clitellata) from

Western Australia

I. Karanovic

A new genus of Candoninae (Crustacea, Ostracoda, Candonidae) from the subterranean waters of southwestern Western Australia

N.K. Cooper, M. Adams, C. Anthony and L.H. Schmitt

Morphological and genetic variation in Leggadina (Thomas, 1910) with special reference to Western Australian populations

M.L. Moir, J.D. Majer and M.J. Fletcher

New records for Hemiptera species in Western Australia

\section{R.A. King}

First valid record of Astacilla Cordiner, 1793 in Australia, with description of a new species (Crustacea: Isopoda: Arcturidae)

\section{SHORT COMMUNICATION}

N.K. Cooper, T. Bertozzi, A. Baynes and R.J. Teale

The relationship between eastern and western populations of the Heath Rat, Pseudomys shortridgei (Rodentia: Muridae) 